\title{
Keep Calm: Archives Between Disasters and Prevention
}

\author{
GRAZIA TATÒ, PH.D. \\ Deputy director of the International Institute for Archival Science of Trieste and Maribor, Via A. La Marmora \\ $17-34139$ Trieste, Italy \\ e-mail: graztat@tin.it
}

Keep Calm: Archives Between Disasters and Prevention

\section{ABSTRACT}

The paper provides the Guidelines for Risk Prevention and Emergency Response in the Archives prepared by Italian Ministry for Cultural Goods and Assets and Tourism in 2014.

Key words: archives, emergencies, security, safety, buildings, interventions

Mantenere la calma: gli archivi tra disastri e prevenzione

\section{SINTESI}

Si presentano qui le Linee guida per la prevenzione dei rischi e la reazione alle emergenze negli Archivi predisposte dal Ministero per i beni culturali e ambientali e il turismo nel 2014.

Parole chiave: archive, emergenze, sicurezza, edifici, interventi

Ostanite mirni: arhivi med nesrečami in njihovim preprečevanjem

IZVLE ČEK

Prispevek predstavlja Smernice za preprečevanje tveganj v arhivih in ukrepanje v nujnih primerih, ki jih je pripravilo italijansko Ministrstvo za kulturne dobrine in turizem v letu 2014.

Ključne besede: arhivi, izredne razmere, varnost, stavbe, posegi

Italian Ministry for Cultural Goods and Assets and Tourism published in 2014 the Guidelines for Risk Prevention and Emergency Response in the Archives, by Monica Calzolari and Cecilia Prosperi. In Italy the need for such a document originated at the urging of natural emergencies caused by earthquake of L'Aquila, from floods in Liguria, Lombardy, Emilia Romagna and, generally, from a territory which unfortunately showed recently all its fragility that imposes the need to plan preventive measures and to have a relief organization effective and widespread.

For the archives, particularly, one should also compare with their fragmented distribution throughout the country, where, in addition to the State Archives, public, private and religious archives can be found: every municipality, hospital, parish, etc. retain relevant documentation for historical, but also administrative and legal purposes. To all these subjects, therefore, must be provided a synthetic and practical help, but also rigorous, in order to prevent or at least contain adverse effects that can be generated by environmental disasters. I believe that knowing of these Guidelines could be useful also to other countries that may still provide a similar tool; and, anyway, they provide themselves as a profitable and systematic document to start an international comparison in order to achieve shared and exportable guidelines.

The many experiences, unfortunately undergone in Italy in managing floods, starting from Florence in 1966, attacks, earthquakes (here we remember the 1976 Friuli, that touched us all), led to consider particularly about intervention methods and techniques, not forgetting that the archives, in addition to being a cultural asset, are also a useful tool to make more effective and efficient the reconstruction operations, the restitution of identity and the protection of the rights of the population. 

disasters.

The European Union itself, moreover, already in 2002 indicated as a priority the prevention of

In Italy the national study group on Risks and Emergencies in the Archives (REA - Rischi ed Emergenze negli Archivi) has actively worked, also in collaboration with the Italian National Archival Association (ANAI - Associazione nazionale archivistica italiana) and other agencies, to encourage research in all fields related to the good preservation of the documentary heritage.

Coming to the analysis of these Guidelines, we will briefly outline their structure, highlighting the proposals.

\section{Disasters}

We distinguish here the natural disasters from those caused by man. Among the first we recall floods, cyclones, volcanic eruptions, rivers flooding, landslides, floods, earthquakes, typhoons, etc.; among the others, wars, attacks, bombings, sabotages, thefts, crackings, nuclear accidents, pollutions, but also neglect, incompetence, general disregard of rules.

\section{Conditions for prevention}

Prevention is implemented through: the provision of an adequate level of safety, constant monitoring, care and control. The protective measures concerning, firstly, the buildings intended for conservation to be anti-seismic, intrusion detection systems, fire alarm and air-conditioning systems. The material must also find a rational arrangement in suitable containers and shelving. Very important, then, the archival procedures of periodic appraisal of the archival material and the subsequent inventory of the historical part. About digital archives, keeping in mind that an archive is a wholeness, regardless of its material nature, the reference is the Digital Administration Code (CAD-Codice dell'Amministrazione Digitale) and the Guidelines for Disaster Recovery of the Digital Italy agency (AGID-Agenzia per l'Italia Digitale).

However, rigorous inventories and detailed surveying will be of great help to the location of the material which, after considering the recovery priorities, will be rescued first. Essential will also be the training and systematic updating of the staff on procedures and safety standards.

\section{Preparing for emergencies}

A careful and rational disaster prevention plan will ensure the quality of results by reducing adverse effects. The risk assessment shall take account of the technical, organizational, procedural and behavioural elements, identifying perpetrators, providing the listing of sources of danger, an ordered preparation of required supporting documentation, such as floor plans, instructions, lists, etc., and providing local operators and materials to them.

\section{Facing emergencies}

The first recommendation is: keep calm!

We will:

- advise managers and the Archival

- organize the intervention teams

- ensure, in order, the safety of persons and installations

- quantify the damage, identify the best method of retrieving assets.

\section{What to do and what not to}

In the case of flooding, floods and tidal waves:

- don't touch and don't stand in water

- do not touch the documentation

- open windows and doors to allow air circulation 
- use dehumidifiers and ventilators

- do not spread sawdust on documentation

- switch off the heating system

- close the water source

- use paper towels, but don't rub the wet material

- providing rags

- remove the dry material.

In case of landslides, volcanic eruptions, and earthquakes:

- move the material in a safe place

- preserve archival signatures and containers

- use equipped containers in order to not dismiss the documentation from the place of origin

- establish a temporary archival pole.

In case of fire:

- contact the Fire Department

- do not fight the fire if you are not sure what to do

- warning no flame embers, no less dangerous

- use suitable extinguishing products.

The guidelines are also accompanied by a series of lists and worksheets about:

- control of external and internal environmental conditions

- furniture

- documents typologies

- media graphics

- the likelihood of disasters

- data about the damaged archival material.

It is finally provided an indication of the related legislation and a book and Web bibliography.

In conclusion, it is, therefore, a comprehensive tool, built on strict technical base and the result of a careful study, but at the same time very practical, and that succeeds in contacting directly and concretely both those who have the responsibility of keeping and those who should have to intervene in time of emergency.

Sharing similar instruments at an international level, comparing them and disseminating them, will be certainly help those working on archives in both ordinary moments and in those, which we hope will not occur ever, but to which we must be prepared to react to, of emergency.

\section{Bibliography}

M. B. BERTINI, La conservazione dei beni archivistici e librari. Prevenzione e piani di emergenza, Roma 2005.

Le carte future. La gestione della sicurezza dei documenti e degli operatori d'archivio. Riflessioni e proposte a trent'anni dal terremoto del Friuli, Trieste 2006.

M. B. BERTINI, I custodi della memoria. L'edilizia archivistica italiana statale del XX secolo, Santarcangelo di Romagna 2014.

MIBACT, Linee guida per la prevenzione dei rischi e la reazione alle emergenze negli Archivi, Roma 2014. 


\section{SUMMARY}

The paper provides the Guidelines for Risk Prevention and Emergency Response in the Archives prepared by Italian Ministry for Cultural Goods and Assets and Tourism in 2014. In Italy a sequence of disasters, mainly due to earthquakes and floods, led to implement a technical tool designed to plan preventive and structural measures to face emergencies and prepare the most appropriate interventions, offering an agile and practical tool both to those who are delegated to the conservation and to those who find themselves to intervene in times of emergency. Hopefully, an international comparison of similar documents in order to improve and share methodologies and solutions will take place.

Typology: 1.02 Review Article

Submitting date: 13.03 .2015

Acceptance date: 09.04.2015 